\title{
Study on Effect of Vitamin E and Chromium Propionate on Milk Composition of Sahiwal Cattle
}

\author{
Mohan Lal Choudhary ${ }^{*}$, Vijay Kumar ${ }^{2}$, Subhash Chandra Goswami ${ }^{2}$, Vijay Kumar ${ }^{2}$, \\ Narender Kumar Poonia ${ }^{2}$ and Rajesh Nehra ${ }^{3}$ \\ ${ }^{1}$ Department of Livestock Production Management, ${ }^{3}$ Department of Animal Nutrition, College \\ of Veterinary and Animal Science, RAJUVAS, Bikaner, Rajasthan, India \\ *Corresponding author
}

\section{A B S T R A C T}

Keywords

Chromium propionate,

Lactation period, Milk yield,

Transition period, Vitamin E

\section{Article Info}

Accepted:

15 November 2018

Available Online:

10 December 2018
An experiment was conducted to investigate the effect of vitamin $\mathrm{E}$ and Chromium propionate during transition period in Sahiwal cows to assess the possibilities of improvement in production performance of supplementation of vitamin $\mathrm{E}$ and Chromium propionate. A total of 28 cows were selected on the basis of their milk yield, parity and body weight are grouped into four homogenous treatment groups of 7 each. No significant effect of supplementation was seen on milk composition. Whereas, numerically higher was observed of lactose, SNF and total solid percent in milk in supplemented group compared to control group. The present study provided evidence of beneficial effect of Vitamin $\mathrm{E}$ and Chromium propionate on milk composition of Sahiwal cattle in transition period.

\section{Introduction}

Dairy is an important and progressive sector of India's national economy and plays a crucial role in the socio economic development. Livestock Sector not only provides essential proteins and nutritious human diet through milk, eggs, meat etc however conjointly plays an important role in utilization of non-edible agricultural byproducts and provides raw material byproducts such as hides, skin, blood, bone, fat etc. Sahiwal is one of the best dairy breeds in
India and Pakistan. It originated from the Sahiwal district of Punjab province in Pakistan. It is tick-resistant, heat-tolerant and noted for its high resistance to parasites, both internal and external. The trace minerals closely involved in the maintenance of normal growth and development, reproduction and health of animals. Deficiency of which may affect productivity, particularly reproduction and health. Provision of adequate mineral and vitamin nutrition during the transition period may be used as a strategy to not only enhance the cow's immunity against disease (Dang et 
al., 2013) but also maintain milk quality and production (Cortinhas et al., 2010). Nikkhah et al., (2010) observed that milk protein percentage increased significantly $(\mathrm{p}<0.01)$ at $\mathrm{Cr}$ supplementation. Whereas, milk fat percentage tended to increase significantly $(\mathrm{p}<0.10)$ and lactose percentage increased significantly $(\mathrm{p}<0.05)$ when $\mathrm{Cr}$ was supplied at $0.05 \mathrm{mg} / \mathrm{kg} \mathrm{BW}^{0.75}$. Rikhari (2008) reported that increasing trend in milk yield and milk composition (fat\%, total solid) was recorded due to increasing level of supplementation of chromium in the ration of productive crossbred cows. However there was no significant effect of chromium supplementation on milk composition viz. SNF, Protein and lactose. Gautam (2015) estimated in different experimental groups to evaluate the effect of chromium supplementation from various sources on milk production and milk composition in lactating Murrah buffaloes. $\mathrm{He}$ found that milk production increase significantly but fortnightly milk composition (fat, protein, lactose, SNF and TS) were statistically similar in all the producing Murrah buffaloes.

\section{Materials and Methods}

An experiment was conducted to investigate the effect of vitamin $\mathrm{E}$ and Chromium propionate during transition period in Sahiwal cows. A total of 28 cows were selected on the basis of their milk yield, parity and body weight are grouped into four homogenous treatment groups of 7 each. Out of these, one group served as control fed as per NRC (2001) wherein no supplementation was given. Cows in treatment groups, Group-1 vitamin E, Group-2 Chromium propionate and Group-3, vitamin $\mathrm{E}+$ Chromium propionate supplementation were given daily along with control diet. The USP(United states Pharmacopia) defines 1 IU OF vitamin $\mathrm{E}$ as equal to $1 \mathrm{mg}$ of $\alpha$-tocopheryl acetate (NRC 2001 ) thus, to supplement 2000 IU of vitamin
E, 2000mg (equivalent to $2 \mathrm{~g}$ ) of $\alpha$-tocopheryl acetateand Chromium propionate $(0.5 \mathrm{mg}$ per $\mathrm{kg}$ of DM) was offered. For milk yield samples were collected at fortnightly and for fat percent milk sample were collected at @ day $7^{\text {th }}, 15^{\text {th }}, 30^{\text {th }}, 45^{\text {th }}$ and $60^{\text {th }}$ day post partum. Milking was done twice a daily and milk yield records were maintained throughout the experimental period. Fat percent was estimated by automatic milk analyzer.

\section{Results and Discussion}

\section{Milk protein percentage}

Milk protein percentage of control and supplemented cows during the early lactation period has been presented in Table 1(a). Protein percentage of milk differed nonsignificantly between groups and different days of lactation period. The interaction effect including group $\mathrm{x}$ days was found nonsignificant. Analysis of variance of milk protein percentage in control and supplemented cows up to 60 days of lactation is presented in Table 1 (b). The highest value of overall mean \pm SE of milk protein percentage was recorded in control group followed by Vitamin E, Chromium propionate and combination supplemented cows. The overall mean values of milk protein percentage of supplemented cows were numerically higher among all groups as compared to the control group.

Similar findings were reported by Sarma (2013) and Saiady et al., (2004) and contrary results were reported by Mutoni et al., (2012) and Uchida et al., (2001).

\section{Milk lactose percentage}

Milk lactose percentage of control and supplemented cows during the early lactation period has been presented in Table 2(a). 
Lactose percentage of milk differed nonsignificantly between groups and different days of lactation period. The interaction effect including group $\mathrm{x}$ days was also found nonsignificant. Analysis of variance of milk protein percentage in control and supplemented cows up to 60 days of lactation is presented in Table 2(b).

The overall Mean \pm SE values of milk lactose percentage of supplemented cows were numerically higher than other supplemented groups, although the difference between the control and other supplemented was found non-significant.

Our results are resembles with Sarma (2013) and Qiang et al., (2009), whereas, contrary results were reported by Mutoni et al., (2012) and Nikkhah et al., (2010).

Table.1(a) Mean ( \pm SE) of milk Protein (\%) in control and supplemented cows

\begin{tabular}{|c|c|c|c|c|c|c|}
\hline \multirow{2}{*}{ Groups } & \multicolumn{5}{|c|}{ Days of lactation } & Overall \\
mean \\
\cline { 2 - 7 } & $\mathbf{7}$ & $\mathbf{1 5}$ & $\mathbf{3 0}$ & $\mathbf{4 5}$ & $\mathbf{6 0}$ & \\
\hline Control & $3.71 \pm 0.22$ & $3.55 \pm 0.19$ & $3.87 \pm 0.31$ & $3.29 \pm 0.04$ & $3.25 \pm 0.04$ & $\mathbf{3 . 5 4} \pm \mathbf{0 . 0 9}$ \\
\hline Supplemented Vitamin E & $3.61 \pm 0.17$ & $3.45 \pm 0.27$ & $3.74 \pm 0.26$ & $3.40 \pm 0.04$ & $3.34 \pm 0.03$ & $\mathbf{3 . 5 1} \pm \mathbf{0 . 0 8}$ \\
\hline $\begin{array}{c}\text { Supplemented Chromium } \\
\text { propionate }\end{array}$ & $3.48 \pm 0.20$ & $3.54 \pm 0.36$ & $3.61 \pm 0.47$ & $3.42 \pm 0.04$ & $3.33 \pm 0.05$ & $\mathbf{3 . 4 8} \pm \mathbf{0 . 1 2}$ \\
\hline $\begin{array}{c}\text { Supplemented combination } \\
\text { Overall mean } \pm \text { SE }\end{array}$ & $3.49 \pm 0.12$ & $3.44 \pm 0.25$ & $3.39 \pm 0.36$ & $3.45 \pm 0.04$ & $3.49 \pm 0.04$ & $\mathbf{3 . 4 5} \pm \mathbf{0 . 0 2}$ \\
\hline & $\mathbf{3 . 5 7} \pm \mathbf{0 . 1 0}$ & $\mathbf{3 . 5 0} \pm \mathbf{0 . 1 4}$ & $\mathbf{3 . 6 5} \pm \mathbf{0 . 1 5}$ & $\mathbf{3 . 3 9} \pm \mathbf{0 . 0 2}$ & $\mathbf{3 . 3 5} \pm \mathbf{0 . 0 2}$ & $\mathbf{3 . 4 9} \pm \mathbf{0 . 0 5}$ \\
\hline
\end{tabular}

Table.1(b) Analysis of variance of milk protein percentage in control and supplemented cows

\begin{tabular}{|c|c|c|c|c|}
\hline Source of variation & DF & SS & Mean Sum of squares & F Ratio \\
\hline Groups & 3 & 0.13 & 0.04 & 0.13 \\
\hline Days & 4 & 1.72 & 0.43 & 1.32 \\
\hline Groups x Day & 12 & 1.37 & 0.11 & 0.35 \\
\hline Residual & 120 & 39.42 & 0.32 & \\
\hline
\end{tabular}

Table.2(a) Mean ( \pm SE) of milk Lactose $(\%)$ in control and supplemented cows

\begin{tabular}{|c|c|c|c|c|c|c|}
\hline \multirow{2}{*}{ Groups } & \multicolumn{5}{|c|}{ Days of lactation } & Overall \\
\cline { 2 - 7 } & $\mathbf{7}$ & $\mathbf{1 5}$ & $\mathbf{3 0}$ & $\mathbf{4 5}$ & $\mathbf{6 0}$ & Mean \\
\hline Control & $4.25 \pm 0.05$ & $4.48 \pm 0.16$ & $4.45 \pm 0.16$ & $4.58 \pm 0.15$ & $4.52 \pm 0.16$ & $\mathbf{4 . 4 5} \pm \mathbf{0 . 0 6}$ \\
\hline $\begin{array}{c}\text { Supplemented } \\
\text { Vitamin E }\end{array}$ & $4.43 \pm 0.17$ & $4.63 \pm 0.12$ & $4.44 \pm 0.15$ & $4.54 \pm 0.13$ & $4.48 \pm 0.14$ & $\mathbf{4 . 5 0} \pm \mathbf{0 . 0 6}$ \\
\hline $\begin{array}{c}\text { Supplemented Cr } \\
\text { Supplemented } \\
\text { combination }\end{array}$ & $4.56 \pm 0.16$ & $4.45 \pm 0.14$ & $4.53 \pm 0.13$ & $4.53 \pm 0.14$ & $4.60 \pm 0.13$ & $\mathbf{4 . 5 3} \pm \mathbf{0 . 0 6}$ \\
\hline Overall Mean \pm SE & $\mathbf{4 . 4 4} \pm \mathbf{0 . 0 7}$ & $4.58 \pm 0.13$ & $4.54 \pm 0.14$ & $4.39 \pm 0.15$ & $4.42 \pm 0.15$ & $\mathbf{4 . 4 9} \pm \mathbf{0 . 0 6}$ \\
\hline
\end{tabular}


Table.2(b) Analysis of variance of milk lactose percentage in control and supplemented cows

\begin{tabular}{|c|c|c|c|c|}
\hline Source of Variation & DF & SS & Mean Sum of squares & F Ratio \\
\hline Groups & 3 & 0.11 & 0.04 & 0.27 \\
\hline Days & 4 & 0.12 & 0.03 & 0.22 \\
\hline Groups x Days & 12 & 0.78 & 0.06 & 0.46 \\
\hline Residual & 120 & 16.85 & 0.14 & \\
\hline
\end{tabular}

Table.3(a) Mean $( \pm$ SE) of SNF (\%) in control and supplemented cows

\begin{tabular}{|c|c|c|c|c|c|c|}
\hline \multirow{2}{*}{ Groups } & \multicolumn{5}{|c|}{ Days of lactation } & $\begin{array}{c}\text { Overall } \\
\text { Mean }\end{array}$ \\
\cline { 2 - 8 } & $\mathbf{7}$ & $\mathbf{1 5}$ & $\mathbf{3 0}$ & $\mathbf{4 5}$ & $\mathbf{6 0}$ & \\
\hline Control & $9.12 \pm 0.21$ & $9.21 \pm 0.46$ & $8.67 \pm 0.24$ & $8.25 \pm 0.24$ & $8.49 \pm 0.32$ & $\mathbf{8 . 7 5} \pm \mathbf{0 . 1 4}$ \\
\hline $\begin{array}{c}\text { Supplemented } \\
\text { Vitamin E }\end{array}$ & $9.38 \pm 0.21$ & $8.73 \pm 0.17$ & $8.75 \pm 0.41$ & $8.61 \pm 0.24$ & $8.49 \pm 0.37$ & $\mathbf{8 . 7 9} \pm \mathbf{0 . 1 3}$ \\
\hline $\begin{array}{c}\text { Supplemented Cr } \\
\text { Supplemented } \\
\text { combination }\end{array}$ & $9.22 \pm 0.35$ & $9.12 \pm 0.35$ & $8.45 \pm 0.36$ & $8.62 \pm 0.43$ & $8.84 \pm 0.49$ & $\mathbf{8 . 8 5} \pm \mathbf{0 . 1 8}$ \\
\hline \begin{tabular}{c} 
Overall mean \pm SE \\
\hline
\end{tabular} & $\mathbf{9 . 1 8} \pm \mathbf{0 . 1 6}$ & $\mathbf{9 . 0 2} \pm \mathbf{0 . 1 9}$ & $\mathbf{8 . 7 1} \pm \mathbf{0 . 1 8}$ & $\mathbf{8 . 5 9} \pm \mathbf{0 . 1 8}$ & $\mathbf{8 . 6 1} \pm \mathbf{0 . 2 1}$ & $\mathbf{8 . 8 2} \pm \mathbf{0 . 0 8}$ \\
\hline
\end{tabular}

Table.3(b) Analysis of variance of SNF in control and supplemented cows

\begin{tabular}{|c|c|c|c|c|}
\hline Source of variation & DF & SS & Mean Sum of squares & F Ratio \\
\hline Groups & 3 & 0.420 & 0.135 & 0.135 \\
\hline Days & 4 & 7.95 & 1.987 & 1.912 \\
\hline Groups x Days & 12 & 3.81 & 0.318 & 0.306 \\
\hline Residual & 120 & 124.72 & 1.04 & \\
\hline
\end{tabular}


Table.4(a) Mean ( \pm SE) of Total solid in control and supplemented cow

\begin{tabular}{|c|c|c|c|c|c|c|}
\hline \multirow[t]{2}{*}{ Groups } & \multicolumn{5}{|c|}{ Days of lactation } & \multirow{2}{*}{$\begin{array}{l}\text { Overall } \\
\text { Mean }\end{array}$} \\
\hline & 7 & 15 & 30 & 45 & 60 & \\
\hline Control & $13.16 \pm 0.22$ & $13.07 \pm 0.46$ & $12.49 \pm 0.25$ & $12.03 \pm 0.34$ & $12.11 \pm 0.33$ & $12.57 \pm 0.16$ \\
\hline $\begin{array}{l}\text { Supplemented } \\
\text { Vitamin E }\end{array}$ & $13.66 \pm 0.20$ & $12.83 \pm 0.18$ & $12.82 \pm 0.42$ & $12.60 \pm 0.28$ & $12.27 \pm 0.40$ & $12.84 \pm 0.15$ \\
\hline Supplemented Cr & $13.31 \pm 0.39$ & $13.14 \pm 0.34$ & $12.36 \pm 0.35$ & $12.52 \pm 0.53$ & $12.59 \pm 0.51$ & $12.78 \pm 0.19$ \\
\hline $\begin{array}{l}\text { Supplemented } \\
\text { combination }\end{array}$ & $13.59 \pm 0.50$ & $13.35 \pm 0.49$ & $13.22 \pm 0.47$ & $12.71 \pm 0.69$ & $12.65 \pm 0.51$ & $13.10 \pm 0.23$ \\
\hline Overall Mean \pm SE & $13.43^{b} \pm 0.17$ & $13.10^{\mathrm{ab}} \pm 0.19$ & $12.72^{\mathrm{ab}} \pm 0.19$ & $12.47^{\mathrm{a}} \pm 0.24$ & $12.41^{\mathrm{a}} \pm 0.21$ & $12.82 \pm 0.09$ \\
\hline
\end{tabular}

Note - Means bearing different superscripts differ significantly.

Table.4(b) Analysis of variance of total solid in control and supplemented cows

\begin{tabular}{|c|c|c|c|c|}
\hline Source of variation & DF & SS & $\begin{array}{c}\text { Mean Sum of square } \\
\text { s }\end{array}$ & F Ratio \\
\hline Groups & 3 & 5.018 & 1.673 & 1.395 \\
\hline Days & 4 & 21.166 & 5.292 & $4.415^{* *}$ \\
\hline Groups x Days & 12 & 3.510 & 0.293 & 0.24 \\
\hline Residual & 120 & 143.83 & 1.199 & \\
\hline
\end{tabular}

Asterisks indicate level of significance $(* * \mathrm{P}<0.01)$

\section{Milk SNF percentage}

Milk SNF percentage of control and supplemented cows during the early lactation period has been presented in Table 3(a). SNF percentage of milk differed non-significantly between groups and different days of lactation period. The interaction effect including group $\mathrm{x}$ days was found non- significant. Analysis of variance of milk SNF percentage in control and supplemented cows up to 60 days of lactation is presented in Table 3(b).

The overall Mean \pm SE values of milk SNF percentage of supplemented cows were numerically higher among all groups as compared to the control group. The difference between the control and other supplemented was non-significant. Similar results were reported by Sarma (2013); Qiang et al., (2009) and Uchida et al., (2001).

\section{Total solid percentage}

Total solid percentage of milk in control and supplemented cows during the early lactation period has been presented in Table 4(a). Total solid percentage of milk differed nonsignificantly between groups but Total solid percentage was found highly significant $(\mathrm{P}<0.01)$ between different days of lactation period. The interaction effect including group $\mathrm{x}$ days was found non- significant. Analysis of variance of milk SNF percentage in control and supplemented cows up to 60 days of lactation is presented in Table 4(b).

The overall mean values of milk total solid percentage of supplemented cows were numerically higher among all supplemented groups as compared to the control group. 


\section{References}

Bourne N, Wathes D C, Lawrence, K E, McGowan M, and Laven R A (2008) The effect of parenteral supplementation of vitamin $\mathrm{E}$ with selenium on the health and productivity of dairy cattle in the UK. The Vet J, 177(3): 381-387

Cortinhas, C S, Botaro, B G, Sucupira, M C A, Renno, F P and Santos, M V (2010) Antioxidant enzymes and somatic cell count in dairy cows fed with organic source of zinc, copper and selenium. Lives Sci, 127: 84-87

Dang A K, Jamwal M, Kaur M, Kimothi S, Pal S De K, Pathan M M, Swain, D K, Mohapatra, S K, Kapila S, Kapila R, Kaur H, Mohanty A K and Prakash B S (2013) Effect of micronutrient supplementation around calving on the plasma cortisol levels of Murrah buffaloes and Sahiwal and Karan Fries cows. Trop Anim Health Prod, 45(4): 1047-1050

Gautam S K (2015) Effect of chromium supplementation on milk production of Murrah buffaloes. M.V.Sc Thesis, dairy cattle nutrition division, ICAR National Dairy Research Institute (deemed university) Karnal-132 001 (Haryana), India.

Mutoni G, Prasad S, Kalyan De, Pal S, Mukherjee J, Kapila S and Dang A K (2012) Effect of supplementation of vitamin E, copper and zinc around peripartum on udder health, milk yield and composition of Sahiwal cows. Livest Res Rur Dev, 24(12).
Nikkhah A M, Mirzaei M, Khorvash H, Rahmani R and Ghorbani G R (2010) Chromium improves production and alters metabolism of early lactation cows in summer. J Anim Physiol Anim Nutr, 95: 81-89.

NRC (2001) Nutrient requirements of dairy cattle, seventh revised ed. National Academy press, Washington, DC.

Qiang J, Zhe-Xi L, Zhang X, Chong-Xi Y and Li X (2009) Evolutionary Development of the Middle Ear in Mesozoic Therian Mammal Sci, 326: 27.

Sarma R (2013) Effect Chromium supplementation of immune-endocrine parameters, nutrient utilization and productive performance in lactating buffaloes. Ph.D Thesis submitted to National Dairy Research Institute (Deemed University) Karnal-132 001 (Haryana), India.

Rikhari K (2008) Effect of supplemental chromium picolinate on rumen metabolism, nutrient utilization, milk yield and its quality in crossbred cattle. Ph.D thesis, G.B. Pant University of Agriculture \& Technology Pantnagar263145, Distt. U.S. Nagar (Uttarakhand), India.

Uchida K, Mandebvu P, Ballard C S, Sniffen C J and Carter M P (2001) Effect of feeding a combination of zinc, manganese and copper amino acid complexes, and cobalt glucoheptonate on performance of early lactation high producing dairy cows. Anim Feed Sci Tech, 93(3): 193-203.

\section{How to cite this article:}

Mohan Lal Choudhary, Vijay Kumar, Subhash Chandra Goswami, Vijay Kumar, Narender Kumar Poonia and Rajesh Nehra. 2018. Study on Effect of Vitamin E and Chromium Propionate on Milk Composition of Sahiwal Cattle. Int.J.Curr.Microbiol.App.Sci. 7(12): 18431848. doi: https://doi.org/10.20546/ijcmas.2018.712.215 